\title{
Melicope oppenheimeri, section Pelea (Rutaceae), a new species from West Maui, Hawaiian Islands: with notes on its ecology, conservation, and phylogenetic placement
}

\author{
Kenneth R. Wood', Marc S. Appelhans ${ }^{2,3}$, Warren L. Wagner ${ }^{3}$ \\ I National Tropical Botanical Garden, 3530 Papalina Road, Kalaheo, HI 96741, USA 2 Department of \\ Systematic Botany, Albrecht-von-Haller Institute of Plant Sciences, University of Göttingen, Untere Karspüle 2, \\ 37073 Göttingen, Germany 3 Department of Botany, Smithsonian Institution, PO Box 37012, Washington, \\ DC 20013-7012, USA
}

Corresponding author: Kenneth R.Wood (kwood@ntbg.org)

Academic editor: P. Acevedo-Rodríguez | Received 14 April 2016 | Accepted 11 August 2016 | Published 25 August 2016

Citation: Wood KR, Appelhans MS, Wagner WL (2016) Melicope oppenheimeri, section Pelea (Rutaceae), a new species from West Maui, Hawaiian Islands: with notes on its ecology, conservation, and phylogenetic placement. PhytoKeys 69: 51-64. doi: 10.3897/phytokeys.69.8844

\begin{abstract}
Melicope oppenheimeri K.R. Wood, Appelhans \& W.L. Wagner (section Pelea (A. Gray) Hook. f., Rutaceae), a rare endemic tree from West Maui, Hawaiian Islands, is described and illustrated with notes on its ecology, conservation, and phylogenetic placement. The new species differs from Hawaiian congeners by its carpels basally connate $1 / 5$, narrowed into a strongly reflexed beak $10-15 \mathrm{~mm}$ long. It also differs in a combination of leaves with 7-10 pair of secondary veins; cymes to $3 \mathrm{~cm}$ long; peduncles $5-6.5 \mathrm{~mm}$ long; flowers perfect; capsules 4-9 × 40-52 mm; and a densely appressed short-sericeous ovary. Melicope oppenheimeri is known only from an isolated cliff-base plateau in upper Waihe'e Valley, West Maui. Its discovery brings the number of recognized Melicope J.R. Forst. \& G. Forst. species in the Hawaiian Islands to 49. A table is included indicating the conservation status of Hawaiian Melicope and Platydesma H. Mann., which is nested within Melicope sect. Pelea.
\end{abstract}

Melicope oppenheimeri falls into the IUCN Critically Endangered (CR) Red List category.

\section{Keywords}

Rutaceae, Melicope, M. section Pelea, new species, Hawaiian Islands, West Maui, Critically Endangered

Copyright Kenneth R. Wood et al. This is an open access article distributed under the terms of the Creative Commons Attribution License (CC BY 4.0), which permits unrestricted use, distribution, and reproduction in any medium, provided the original author and source are credited. 


\section{Introduction}

Melicope J.R. Forst. \& G. Forst. is the largest genus of the Citrus family (Rutaceae) and consists of ca. 235 species of shrubs and trees (Hartley 2001, Appelhans et al. 2014a). The distribution of Melicope ranges from the Malagasy and Indo-Himalayan regions in the east to the Hawaiian and Marquesan Islands in the west and from Nepal, southern China, Taiwan and the Japanese Ogasawara Islands in the north to New Zealand and Australia in the south (Hartley 2001). Ongoing phylogenetic studies of Melicope and closely related genera indicate the need for revisionary work in this group with several of the related small genera belonging in Melicope in order for it to be monophyletic (Harbaugh et al. 2009, Appelhans et al. 2014b). In the most recent systematic revision by Hartley (2001) Melicope was subdivided into four sections: Lepta (Lour.) T.G. Hartley; Melicope; Pelea (A. Gray) Hook. f.; and Vitiflorae T.G. Hartley. Only section Lepta proved to be a monophyletic group in a recent molecular study (Appelhans et al. 2014b). The currently known 48 endemic Hawaiian species are all members of sect. Pelea, which consists of 85 species almost exclusively restricted to the Australasian-Outer Melanesian-Pacific region. Within sect. Pelea, only the Hawaiian group proved to be monophyletic (Appelhans et al. 2014c). The Hawaiian endemic species all have unifoliolate leaves; plants presumably hermaphroditic or dioecious; carpels that range from being basally connate to fully connate, and with variations in exocarp and endocarp that contrast from glabrous to pubescent. Hartley (2001) inferred that Melicope was present in eastern Gondwanaland before about $96 \mathrm{Ma}$ and states that the Hawaiian species represent a radiation that most likely traces back to a single colonization of the archipelago by a species from sect. Pelea. While Hartley's age estimate of Melicope is doubtful since the oldest fossils of the whole family date to the Late Cretaceous (Knobloch and Mai 1986, Gregor 1989) and molecular dating studies estimated its origin in the Oligocene or Miocene (Muellner et al. 2007, Appelhans et al. 2012), his suggestion for a single colonization of the Hawaiian archipelago was supported by molecular phylogenetic analyses (Harbaugh et al. 2009, Appelhans et al. 2014b, c). The most recent molecular phylogenetic studies also indicate that the Hawaiian genus Platydesma H. Mann is nested within Melicope sect. Pelea and that the seven known Marquesan Melicope endemics are a closely related group resultant from two independent colonization events from Hawaiian Melicope (Harbaugh et al. 2009, Appelhans et al. 2014c).

\section{Methods}

All measurements and descriptions were taken from dried herbarium specimens or from notes made in the field and are presented in the descriptions as follows: length $x$ width, followed by units of measurement $(\mathrm{mm}$ or $\mathrm{cm})$. 


\section{Taxonomic treatment}

Melicope oppenheimeri K.R. Wood, Appelhans \& W.L. Wagner, sp. nov. urn:lsid:ipni.org:names:60472944-2

Figs 1, 4, 5

Diagnosis. Differs from Hawaiian congeners by its combination of leaves having 7-10 pair of secondary veins; cymes to $3 \mathrm{~cm}$ long; peduncles 5-6.5 $\mathrm{mm}$ long; flowers perfect; carpels basally connate $1 / 5$, narrowed into a strongly reflexed beak $10-15 \mathrm{~mm}$ long, capsules 4-9 × 40-52 mm; and ovary appressed densely short-sericeous.

Type. United States of America. Hawaiian Islands, West Maui: Wailuku District, Waihe'e Valley, Metrosideros polymorpha var. glaberrima-Cheirodendron trigynum wet forest, $20^{\circ} 54.15^{\prime} \mathrm{N} ; 156^{\circ} 33.95^{\prime} \mathrm{W}, 770 \mathrm{~m}$ elev., 12 Sep 2006, Hank Oppenheimer \& Jill Miller 190609 (holotype: PTBG-070667; isotypes: BISH, US)

Description. Trees 3-4 m tall, bark medium brown, young branchlets light brown, glabrate, 3-6 $\mathrm{mm}$ wide in third internode, terminal branchlets yellowish brown tomentose with a waxy scurf. Leaves opposite, unifoliolate, coriaceous, the blade obovate to broadly elliptic, occasionally orbicular, $5-17.5 \times 3.5-8.5 \mathrm{~cm}$, the margin entire, the base rounded to obtuse, the apex rounded, obtuse to acute, or emarginate, secondary veins usually 7-10 pairs, connected by a moderately arched vein 2-11 $\mathrm{mm}$ from margin with higher order venation reticulate, both surfaces glabrous, occasionally glabrate along midrib of abaxial surface, young leaves glabrate to sparsely puberulent on lower surface; petiole shallowly canaliculate, $10-30 \times 1-3 \mathrm{~mm}$ at middle, glabrate. Flowers: perfect, 3-5 in axillary cymes up to $3 \mathrm{~cm}$ long, peduncles 5-6.5 $\mathrm{mm}$ long, sparsely short-puberulent, pedicles $5-8 \mathrm{~mm}$, short-puberulent, bracteoles $1.5-3 \mathrm{~mm}$ long, sepals broadly ovate, tip short acuminate, externally sparsely shortpuberulent, glabrous within, $3 \times 2.5-2.8 \mathrm{~mm}$, connate basally $1 / 4$ to $1 / 3$ of length; petals tinged purple, narrowly ovate, lanceolate, $6-8 \times 2.5-3 \mathrm{~mm}$, glabrous internally and externally, tips recurved, nectary disk with sparsely scattered hairs; ovary densely appressed short-sericeous; style ca. $1.7 \mathrm{~mm}$ long, with finely appressed hairs; stigma capitate, four lobed, glabrous; stamens 8 , filaments glabrous, the antesepalous ones 5-7 mm long, antepetalous ones 4-5 mm long, all with pollen. Capsules purple tinged when fresh, 4-9 $\times 40-52 \mathrm{~mm}$, carpels connate basally for ca. 1/5 their length, narrowed into a strongly reflexed beak $10-15 \mathrm{~mm}$ long, exocarp glabrate with few hairs widely spaced over surface, endocarp sparsely to evenly puberulent. Seeds 2 per carpel, ovoid, 5-9 mm long.

Phenology. To date, Melicope oppenheimeri has been observed with flower buds in January and August, with flowers at anthesis during September, and with fruit during January, February, May, August, September, and November.

Etymology. We are pleased to name this new species in honor of Hank Oppenheimer, botanist with the Maui Nui Plant Extinction Prevention Program, who collected the type specimen and has made many valuable contributions to the understanding and conservation of the Hawaiian flora. 


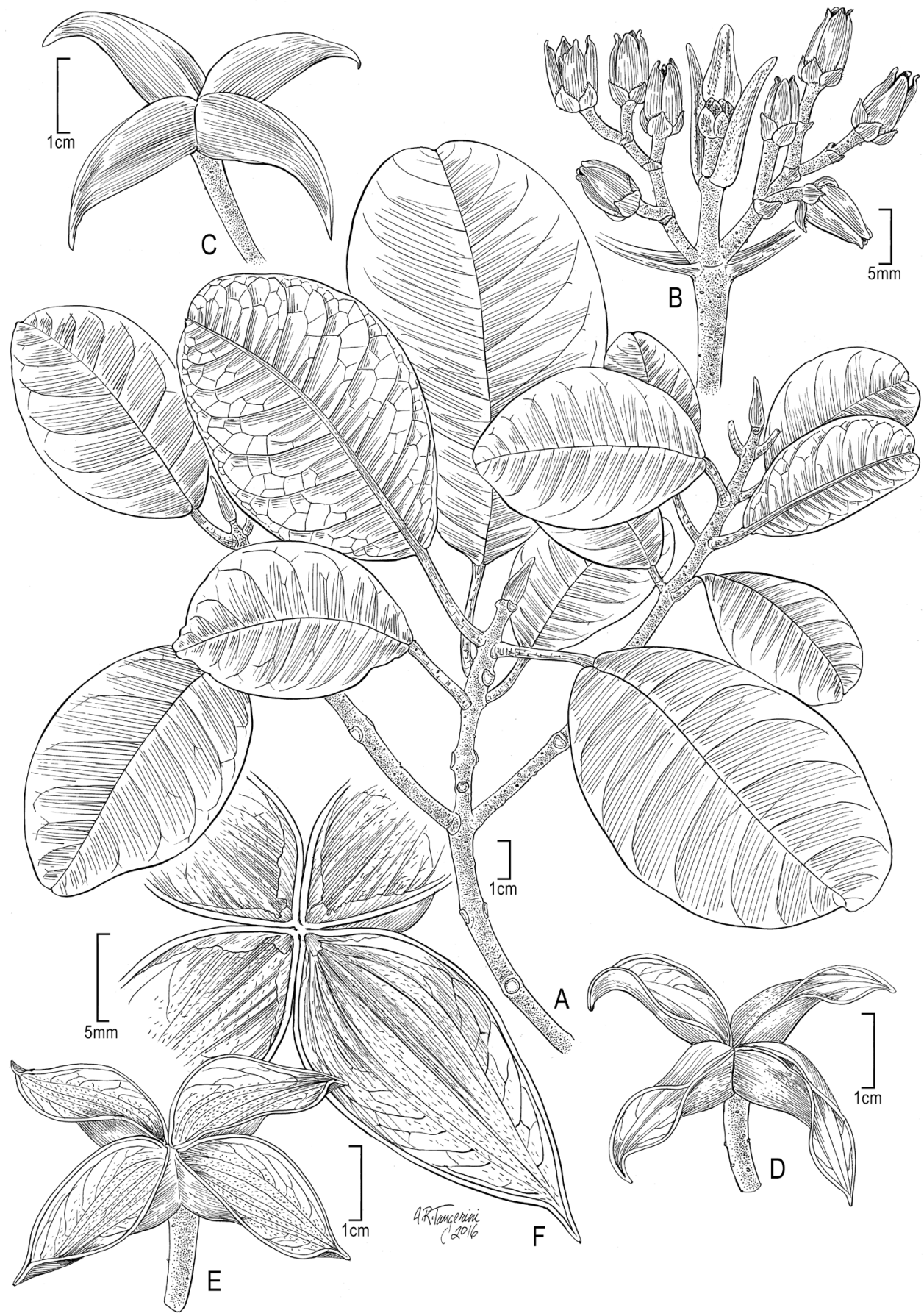

Figure I. Melicope oppenheimeri K.R. Wood, Appelhans \& W.L. Wagner. A Flowering branch, Oppenheimer \& Hansen H20505 (PTBG) B Inflorescence C Undehisced fruit, showing beaked carpels D Fruit, partly open E Fruit, fully opened $\mathbf{F}$ Fruit endocarp showing venation and hairs B-F from Oppenheimer \& Miller H90609 (PTBG) (Illustration by Alice Tangerini). 
Specimens examined. United States. Hawaiian Islands, West Maui: Wailuku District, Waihe'e Valley, south side, below and north of Kahoolewa Ridge, $20^{\circ} 54.15^{\prime} \mathrm{N} ; 156^{\circ} 33.95^{\prime} \mathrm{W}, 770 \mathrm{~m}$ elev., 8 Aug 1998, Wood \& Perlman 7408 (BISH, PTBG, US); loc. cit., 9 Aug 1998, Perlman \& Wood 16,338 (CANB, PTBG); loc. cit., 10 AUG 1998, Wood \& Perlman 7419 (BISH, PTBG, US); loc. cit., 15 Feb 2005, Oppenheimer \& Hansen H20,505 (BISH, PTBG, US); loc. cit., 19 May 2009, Perlman \& Oppenheimer 21,642 (PTBG).

The following couplets can be inserted into the existing key to Hawaiian Melicope (treated as Pelea) by Stone, Wagner, and Herbst (in Wagner et al. 1999, pp. 11791182) to accommodate M. oppenheimeri.

19(18) Exocarp sparsely to densely puberulent or tomentose, at least toward base or along suture

19 Exocarp glabrous or glabrate, sometimes with a few hairs widely spaced over surface

49(19) Endocarp densely and uniformly short-villous; K.......................... cruciata

49 Endocarp glabrous or sparsely puberulent, especially along suture ............50

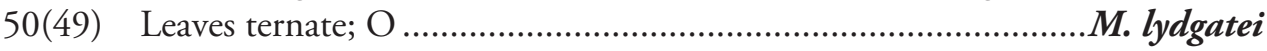

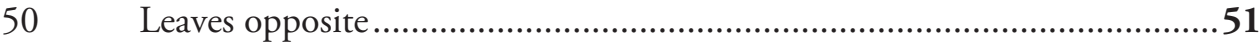

51(50) Most petioles 0-10 mm long .............................................................52

$51 \quad$ Most petioles over $10 \mathrm{~mm}$ long ………….......................................58

58(51) Ovary sparsely to densely puberulent or tomentulose, but exocarp glabrate or

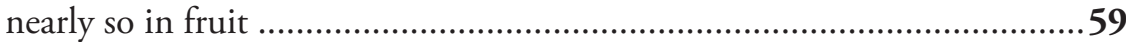

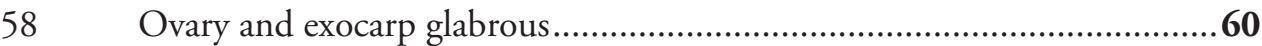

59(58) Flowers perfect, carpels narrowed into a reflexed beak 10-15mm long; WM ... M. oppenheimeri

59 Flowers unisexual, carpels straight or somewhat reflexed, apex not beaked ... $59 a$

59a(59) Capsules (16-)25-40(-50) mm wide, carpels connate 1/4-1/3 their length; pedicels 5-20 mm long; L, EM, $\mathrm{H}$ M. volcanica

59a Capsules 11-20 mm wide, carpels connate (1/3-) 1/2 their length or more; pedicels $2-5 \mathrm{~mm}$ long; $\mathrm{K}, \mathrm{O}$

M. wawraeana

Distribution and ecology. Although seven trees of Melicope oppenheimeri have been documented since its discovery in 1998, only three trees are still surviving in the upper headwaters of Waihe'e Valley, West Maui (Figures 2, 3). No trees have yet been located outside of the type locality and access to the site has only been by helicopter.

The plant communities of upper Waihe'e Valley are varied and merge together in and around the $0.25 \mathrm{~km}^{2}$ cliff-base plateau region where trees of Melicope oppenheimeri occur. The plateau itself represents a relictual low statured Metrosideros Banks ex Gaertn. (Myrtaceae)-Cheirodendron Nutt. ex Seem. (Araliaceae) lowland wet forest community. Other relic native components of the plateau include ferns such as Asplenium lobulatum Mett. (Aspleniaceae), Cibotium glaucum (Sm.) Hook. \& Arn. (Cibotiaceae), Ctenitis 


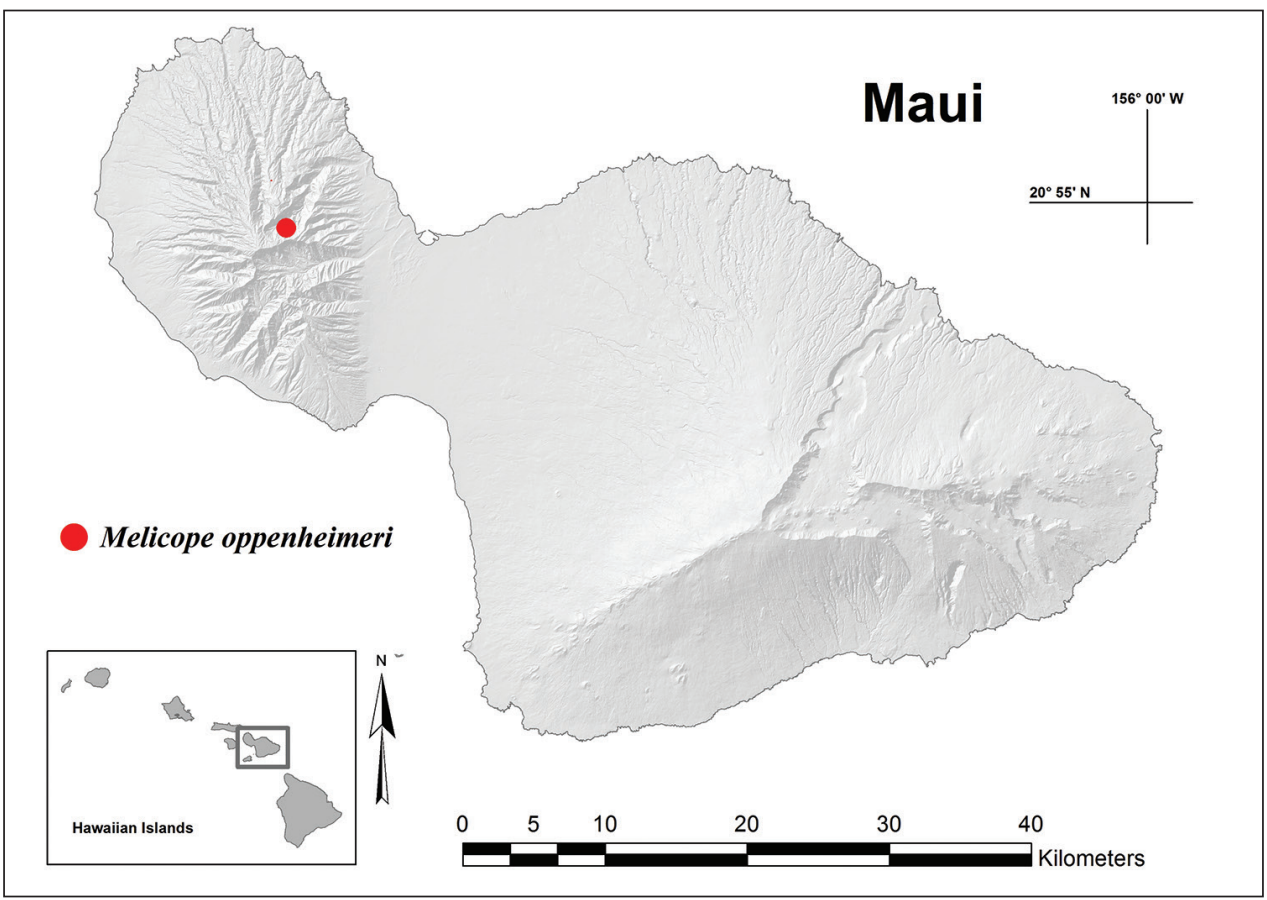

Figure 2. Map of Maui, Hawai'i showing location of Melicope oppenheimeri in upper Waihe'e Valley.

latifrons (Brack.) Copel. (Dryopteridaceae), Diplazium sandwichianum (C. Presl) Diels (Athyriaceae), two endemic genera of ferns, namely Adenophorus Gaudich. (Polypodiaceae) and Sadleria Kaulf. (Blechnaceae), along with herbs, shrubs, and small trees including Antidesma platyphylla H. Mann (Phyllanthaceae), Broussaisia arguta Gaudich. (Hydrangeaceae), Coprosma pubens A. Gray (Rubiaceae), Dubautia plantaginea Gaudich. (Asteraceae), Peperomia hirtipetiola C. DC. (Piperaceae), and various species of Clermontia Gaudich., Cyanea Gaudich. (both Campanulaceae), and Cyrtandra J.R. Forst. \& G. Forst. (Gesneriaceae). Steeper ridges and slopes that edge the plateau are dominated by matting ferns of Dicranopteris Bernh.(Gleicheniaceae) (Wood 1997).

Unfortunately, past habitat degradation by introduced pigs (Sus scrofa L.) has altered the plant composition of the plateau, which is now being dominated by a succession of invasive weeds, which threaten Melicope oppenheimeri, especially Ageratina adenophora (Spreng.) R.M. King \& H. Rob. (Asteraceae), Buddleja asiatica Lour. (Scrophulariaceae), Clidemia hirta (L.) D. Don (Melastomataceae), Erigeron karvinskianus DC. (Asteraceae), and Tibouchina herbacea (DC.) Cogn. (Melastomataceae) (Wood 1997).

Towering over the plateau and most outstanding, are vertical caldera-like basalt cliffs dominated by a native sedge and grass association called Machaerina Vahl (Cyperaceae)-Deschampsia P. Beauv. (Poaceae) wet cliff community. The cliffs are seeping with springs and waterfalls and strata of past volcanic flows are clearly evident. Additional components of this Waihe'e cliff community include Sadleria pallida 


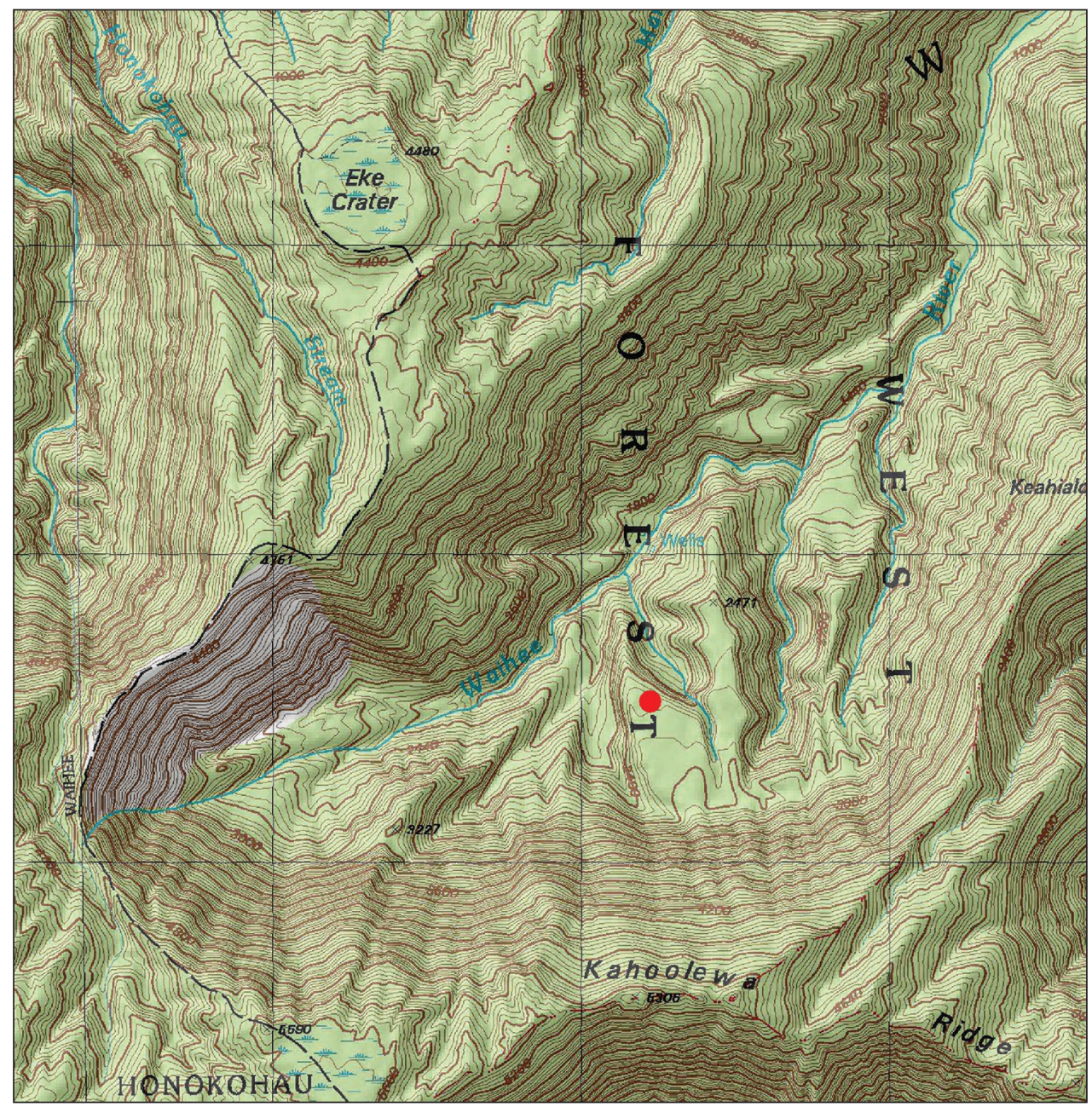

Figure 3. Map of upper Waihe'e Valley, West Maui, with red dot indicating the location of Melicope oppenheimeri on the cliff-base plateau region.

Hook. \& Arn., Pipturus albidus (Hook. \& Arn.) A. Gray (Urticaceae), Eragrostis grandis Hillebr., Isachne distichophylla Munro ex Hillebr. (both Poaceae), and Dubautia scabra (DC.) D.D. Keck.

Superb examples of Metrosideros-Cheirodendron montane wet forest dominate above these cliffs in association with windswept wet shrublands and occasional bog communities in and around the locality known as Kaho'olewa Ridge (Wood 1997). At the base of the cliffs, which enclose the southern perimeter of the plateau lie heaps of basalt talus with accumulated substrates which are moderately deep in sections and appear to be fine textured brown silty clay.

The forests spreading below the plateau are composed of Metrosideros mixed lowland riparian vegetation, which are closed to open in canopy and dissected by deeply 


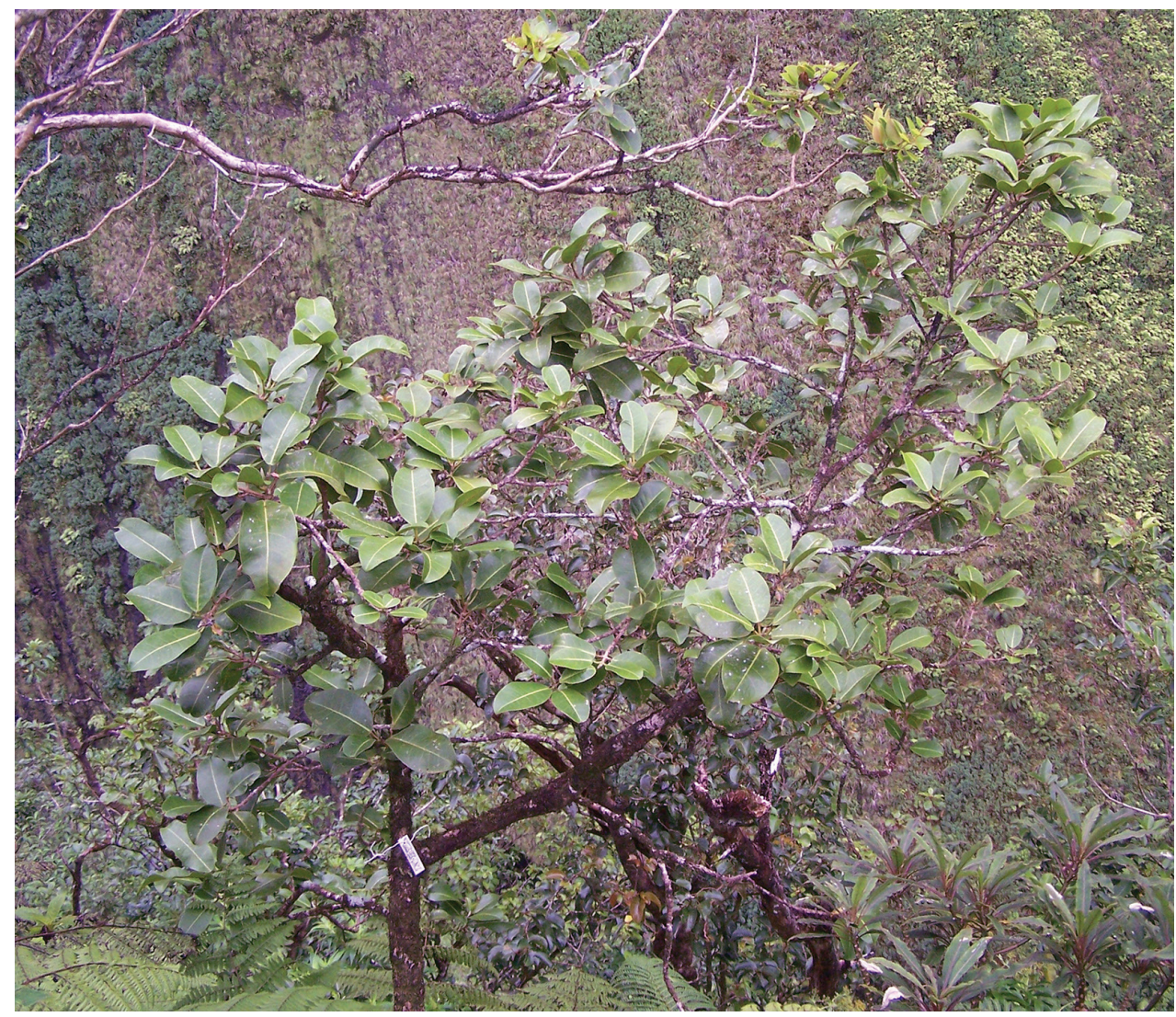

Figure 4. Habit of Melicope oppenheimeri (Oppenheimer \& Miller H90609). Photo by H. Oppenheimer, 12 Sep 2006.

carved streams with steep banks $10-30 \mathrm{~m}$ in height. The native flora of this lower riparian community has similarities to the cliff-base plateau but with a greater diversity, including Ilex anomala Hook. \& Arn. (Aquifoliaceae), Perrottetia sandwicensis A. Gray (Dipentodontaceae), Polyscias oahuensis (A. Gray) Lowry \& G.M. Plunkett (Araliaceae), and Pritchardia forbesiana Rock (Arecaceae), along with species of Kadua Cham. \& Schltdl. (Rubiaceae), Myrsine L. (Primulaceae), and Psychotria L. (Rubiaceae) (Wood 1997). Notable observations of native birds in the upper Waihe'e region include nesting seabird colonies of dark-rumped petrels (Pterodroma sandwichensis Ridgeway) along with native forest birds such as 'apapane (Himatione sanguinea Gmelin), and 'amakihi (Chlorodrepanis virens wilsoni Rothschild).

Phylogenetic placement. Melicope oppenheimeri, like all Hawaiian Melicope, falls into section Pelea, which has a distribution ranging from Taiwan, the Philippines, and Borneo eastward to the Hawaiian and Marquesas Islands, and south to New Caledonia. Only Melicope triphylla (Lam.) Merr. is distributed in the Southeast Asian areas mentioned above, and the remainder of sect. Pelea is restricted to New Guinea and Pa- 
cific archipelagos (Hartley 2001). Section Pelea proved to be polyphyletic in molecular phylogenetic analyses, and monophyly can be reached if the New Caledonian species are excluded and the Hawaiian endemic genus Platydesma is included in the section (Appelhans et al. 2014b). Hartley (2001, pp. 31, 139-140) stated that the Hawaiian species mostly resemble the New Caledonian species - especially M. vieillardii - based on several "primitive" characters including bisexual flowers, persistent sepals and petals, apically acute staminal filaments, basally connate carpels, glabrous endocarp, and Type A seed attachment, however, a close phylogenetic relationship of the Hawaiian and the New Caledonian species could not be verified (Appelhans et al. 2014b). The Hawaiian species of Melicope have been treated under the genus Pelea by Wagner et al. (1990) and the authors divided the taxon into the four sections Apocarpa B. Stone; Cubicarpa B. Stone; Megacarpa B. Stone; and Pelea. If the Hawaiian groups are to continue to be recognized, they would need to be treated as subsections. Only the latter of these sections, which consists of three species, proved to be monophyletic (Appelhans et al. 2014b, c). Two specimens of Melicope oppenheimeri (the paratypes Wood \& Perlman 7408 and Wood \& Perlman 7419) have been included in phylogenetic research (Appelhans et al. 2014b, c) and they are listed under the original determination Melicope reflexa (H. St. John) T.G. Hartley \& B.C. Stone in these studies. The two specimens are part of a largely unresolved clade consisting of representatives of Cubicarpa and Megacarpa. The closest relatives of $M$. oppenheimeri could not be determined due to the low genetic variation in the sampled nuclear and plastid markers. We are currently working on resolving phylogenetic relationships of Hawaiian Melicope using Next-generation sequencing.

Morphology and related taxa. Although beaked fruit have evolved in a few species of Melicope belonging to sections Melicope and Vitiflorae (Hartley 2001, p. 19), this character is unique to M. oppenheimeri within sect. Pelea (Figure 1C, 5B). Beaked fruit have also evolved in Hawaiian Platydesma sect. Cornutia B.C. Stone, which is nested within Melicope sect. Pelea, but which is not an immediate relative of $M$. oppenheimeri.

Morphologically, Melicope oppenheimeri resembles the Moloka'i endemic species $M$. reflexa, with both having reflexed carpels that are coherent at base. Significant differences between $M$. oppenheimeri and M. reflexa include capsules connate 1/5, 4-9 $\times 40-52 \mathrm{~mm}$ (vs. capsules connate $1 / 4,10-17 \times 20-33 \mathrm{~mm}$ ); endocarp sparsely to evenly puberulent (vs. endocarp glabrous); ovary appressed densely short-sericeous (vs. ovary glabrous); pedicles 5-8 $\mathrm{mm}$ (vs. pedicles $15-20 \mathrm{~mm}$ ); and flowers perfect, 3-5, on robust peduncles (vs. flowers unisexual, 1-3, on delicate peduncles).

Two other morphologically similar Hawaiian Melicope, also with carpels coherent at base include M. molokaiense (Hillebr.) T.G. Hartley \& B.C. Stone and M. volcanica (A. Gray) T.G. Hartley \& B.C. Stone. Melicope molokaiense, which is known from Molokai and Maui, differs from M. oppenheimeri in having capsules connate 1/4, 10-17 × 21-39 mm; endocarp glabrous; ovary glabrous; and flowers unisexual. Melicope volcanica, which is known from Lana $i$, Moloka $i$, East Maui, and the big island of Hawai $i$, similarly differs with capsules connate $1 / 3-1 / 4$, and flowers unisexual, yet 


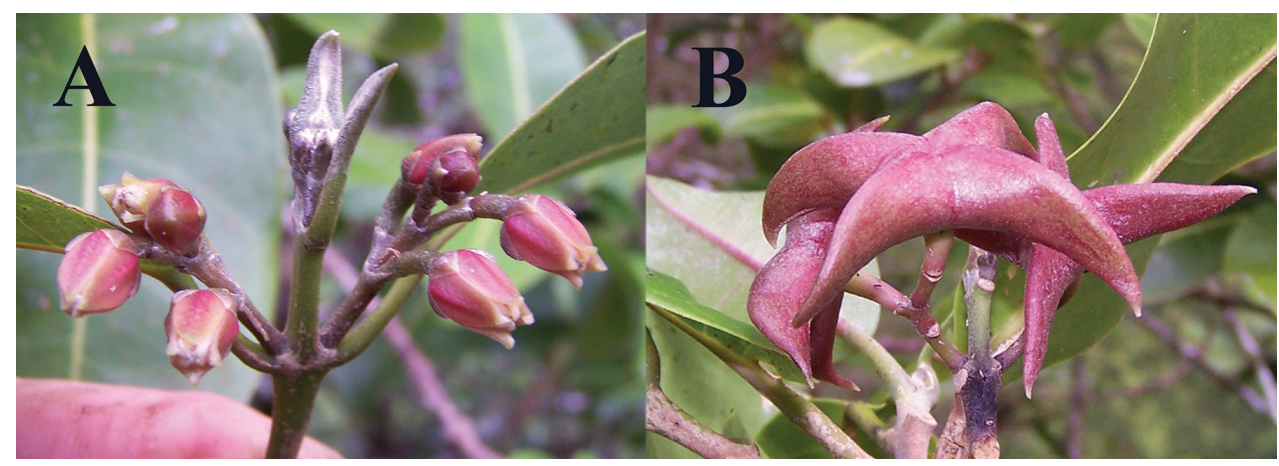

Figure 5. Melicope oppenheimeri A Flowers B Fruit, showing beaked carpels (Oppenheimer \& Miller H90609). Photos by H. Oppenheimer, 12 Sep 2006.

also differs with leaves having 10-20 pair of secondary veins; cymes ca. $6 \mathrm{~cm}$ long; and peduncles 7-38 mm long. Melicope oppenheimeri has leaves with 7-10 pair of secondary veins; cymes ca. $3 \mathrm{~cm}$ long; and peduncles $5-6.5 \mathrm{~mm}$ long.

Melicope species are generally either exclusively hermaphroditic or dioecious, yet there are a few recorded exceptions (Hartley 2001, p. 10). Although M. oppenheimeri is apparently hermaphroditic, we cannot make a definitive statement on the breeding system of this rare narrow endemic, having only six collections for study, and limited flowering material.

Conservation status. Plant and animal endemics from isolated oceanic islands are often endangered or critically endangered (Kreft et al. 2008, Sakai et al. 2002). The ongoing decline of native pollinators (Kearns et al. 1998) and seed dispersers (Milberg and Tyrberg 1993), in combination with other primary extrinsic factors such as invasive non-native plants, predation by introduced vertebrates, loss and fragmentation of natural habitats, and devastation by severe storms, are leading to an increase in extinctions throughout the islands of Oceania (Sakai et al. 2002, Wood 2007, 2012, Kingsford et al. 2009). Other prominent factors such as strict habitat requirements, very low historic population densities and narrow geographic range increase the risk of extinction. (Sakai et al. 2002, Wood 2007, 2015). It is currently unclear how many of the estimated 10,000 native Hawaiian insect species have gone extinct, but at this point in time the Hawaiian Islands have lost 79 of its native bird species and are left with only 32 (James and Olson 1991, Olson and James 1991, Burney et al. 2001, Boyer 2008). The authors maintain a checklist of endemic Hawaiian vascular plant taxa that have no known wild individuals remaining. Of the estimated 1191 native vascular plant species in Hawai $i$, 130 taxa are now presumed extinct. Evidently 41 of these possible extinctions have occurred in the Hawaiian lobeliads (Campanulaceae), a family renowned for their co-evolution with Hawai'i's unique forest birds, the honeycreepers, in the endemic subfamily Drepanidinae of the Fringillidae or finch family (Wood 2014, 2015). The Lamiaceae or mint family falls second in this severe category, with 22 species that are presumed extinct. With two-thirds of the surviving forest bird species in Hawai $i$ being critically 
Table I. Checklist of endemic Hawaiian Melicope and Platydesma with conservation status and island distribution. (Status Symbols: C=candidate for federal listing; E=federally listed as endangered; EX=possibly extinct; PEPP=Plant Extinction Prevention Program (50 or less individuals known in wild); SOC=species of concern. Island Distribution: K=Kaua ${ }^{\prime} ;$; $\mathrm{O}=\mathrm{O}$ 'ahu; Mo=Moloka $\mathrm{i}$; L=Lana $\mathrm{i}$; M=Maui; H=Big Island of Hawai i; Note: Platydesma had been shown to be nested in Melicope [Harbaugh et al. 2009, Appelhans et al. 2014c]).

\begin{tabular}{|c|c|c|}
\hline Taxon & Status & Distribution \\
\hline Melicope adscendens (H.St.John \& E.P.Hume) T.G.Hartley \& B.C.Stone & E, PEPP & $\mathrm{M}$ \\
\hline Melicope anisata (H.Mann) T.G.Hartley \& B.C.Stone & & $\mathrm{K}$ \\
\hline Melicope balloui (Rock) T.G.Hartley \& B.C.Stone & $\mathrm{E}, \mathrm{EX}$ & M \\
\hline Melicope barbigera A.Gray & & $\mathrm{K}$ \\
\hline Melicope christophersenii (H.St.John) T.G.Hartley \& B.C.Stone & $\mathrm{E}$ & $\mathrm{O}$ \\
\hline Melicope cinerea A.Gray & SOC & $\mathrm{O}$ \\
\hline Melicope clusiifolia (A.Gray) T.G.Hartley \& B.C.Stone & & $\mathrm{K}, \mathrm{O}, \mathrm{Mo}, \mathrm{L}, \mathrm{M}, \mathrm{H}$ \\
\hline Melicope cruciata (A.Heller) T.G.Hartley \& B.C.Stone & SOC & $\mathrm{K}$ \\
\hline Melicope degeneri (B.C.Stone) T.G.Hartley \& B.C.Stone & E, PEPP & $\mathrm{K}$ \\
\hline Melicope elliptica (A.Gray) T.G.Hartley \& B.C.Stone & & $\mathrm{O}, \mathrm{Mo}, \mathrm{M}$ \\
\hline Melicope feddei (H.Lév.) T.G.Hartley \& B.C.Stone & & $\mathrm{K}$ \\
\hline Melicope haleakalae (B.C.Stone) T.G.Hartley \& B.C.Stone & SOC & M \\
\hline Melicope haupuensis (H.St.John) T.G.Hartley \& B.C.Stone & E, PEPP & $\mathrm{K}$ \\
\hline Melicope hawaiensis (Wawra) T.G.Hartley \& B.C.Stone & SOC & Mo, L, M, H \\
\hline Melicope hiiakae (B.C.Stone) T.G.Hartley \& B.C.Stone & $\mathrm{E}$ & $\mathrm{O}$ \\
\hline Melicope hosakae (H.St.John) W.L.Wagner \& R.K.Shannon & & $\mathrm{O}$ \\
\hline Melicope kaalaensis (H.St.John) T.G.Hartley \& B.C.Stone & & $\mathrm{O}$ \\
\hline Melicope kavaiensis (H.Mann) T.G.Hartley \& B.C.Stone & & $\mathrm{K}$ \\
\hline Melicope knudsenii (Hillebr.) T.G.Hartley \& B.C.Stone & E, PEPP & $\mathrm{K}, \mathrm{M}$ \\
\hline Melicope lydgatei (Hillebr.) T.G.Hartley \& B.C.Stone & E, PEPP & $\mathrm{O}$ \\
\hline Melicope macropus (Hillebr.) T.G.Hartley \& B.C.Stone & EX, SOC & $\mathrm{K}$ \\
\hline Melicope makahae (B.C.Stone) T.G.Hartley \& B.C.Stone & $\mathrm{E}$ & $\mathrm{O}$ \\
\hline Melicope molokaiensis (Hillebr.) T.G.Hartley \& B.C.Stone & & Mo, M \\
\hline Melicope mucronulata (H.St.John) T.G.Hartley \& B.C.Stone & E, PEPP & Mo, M \\
\hline Melicope munroi (H.St.John) T.G.Hartley \& B.C.Stone & $\mathrm{E}$ & Mo, L \\
\hline Melicope nealae (B.C.Stone) T.G.Hartley \& B.C.Stone & EX, SOC & $\mathrm{K}$ \\
\hline Melicope oahuensis (H.Lév.) T.G.Hartley \& B.C.Stone & & $\mathrm{O}$ \\
\hline Melicope obovata (H.St.John) T.G.Hartley \& B.C.Stone & EX, SOC & $\mathrm{M}$ \\
\hline Melicope oppenheimeri K.R.Wood, Appelhans \& W.L.Wagner & PEPP & M \\
\hline Melicope orbicularis (Hillebr.) T.G.Hartley \& B.C.Stone & & $\mathrm{M}$ \\
\hline Melicope ovalis (H.St.John) T.G.Hartley \& B.C.Stone & $\mathrm{E}$ & M \\
\hline Melicope ovata (H.St.John \& E.P.Hume) T.G.Hartley \& B.C.Stone & & $\mathrm{K}, \mathrm{O}$ \\
\hline Melicope pallida (Hillebr.) T.G.Hartley \& B.C.Stone & E & $\mathrm{K}, \mathrm{O}$ \\
\hline Melicope paniculata (H.St.John) T.G.Hartley \& B.C.Stone & E & $\mathrm{K}$ \\
\hline Melicope peduncularis (H.Lév.) T.G.Hartley \& B.C.Stone & & $\mathrm{K}, \mathrm{O}, \mathrm{Mo}, \mathrm{M}$ \\
\hline Melicope pseudoanisata (Rock) T.G.Hartley \& B.C.Stone & & $\mathrm{M}, \mathrm{H}$ \\
\hline Melicope puberula (H.St.John) T.G.Hartley \& B.C.Stone & $\mathrm{E}$ & $\mathrm{K}$ \\
\hline $\begin{array}{l}\text { Melicope quadrangularis (H.St.John \& E.P.Hume) T.G.Hartley \& } \\
\text { B.C.Stone }\end{array}$ & E, PEPP & $\mathrm{K}$ \\
\hline Melicope radiata (H.St.John) T.G.Hartley \& B.C.Stone & & $\mathrm{H}$ \\
\hline
\end{tabular}




\begin{tabular}{l|c|c}
\hline Taxon & Status & Distribution \\
\hline Melicope reflexa (H.St.John) T.G.Hartley \& B.C.Stone & E, PEPP & Mo \\
\hline Melicope rotundifolia (A.Gray) T.G.Hartley \& B.C.Stone & & $\mathrm{O}$ \\
\hline Melicope saint-johnii (E.P.Hume) T.G.Hartley \& B.C.Stone & $\mathrm{E}$ & $\mathrm{O}$ \\
\hline Melicope sandwicensis (Hook. \& Arn.) T.G.Hartley \& B.C.Stone & SOC & $\mathrm{O}$ \\
\hline Melicope sessilis (H.Lév.) T.G.Hartley \& B.C.Stone & & Mo, M \\
\hline Melicope volcanica (A.Gray) T.G.Hartley \& B.C.Stone & & Mo, L, M, H \\
\hline Melicope waialealae (Wawra) T.G.Hartley \& B.C.Stone & & $\mathrm{K}$ \\
\hline Melicope wailauensis (H.St.John) T.G.Hartley \& B.C.Stone & EX, SOC & Mo \\
\hline Melicope wawraeana (Rock) T.G.Hartley \& B.C.Stone & & $\mathrm{K}, \mathrm{O}$ \\
\hline Melicope zahlbruckneri (Rock) T.G.Hartley \& B.C.Stone & E, PEPP & $\mathrm{H}$ \\
\hline Platydesma cornuta Hillebr. var. cornuta & $\mathrm{E}$ & $\mathrm{O}$ \\
\hline Platydesma cornuta Hillebr. var. decurrens B.C.Stone & $\mathrm{E}$ & $\mathrm{O}$ \\
\hline Platydesma remyi (Sherff) O.Deg., I.Deg, Sherff \& B.C.Stone & $\mathrm{C}, \mathrm{PEPP}$ & $\mathrm{H}$ \\
\hline Platydesma rostrata Hillebr. & $\mathrm{E}$ & $\mathrm{K}$ \\
\hline Platydesma spathulata (A.Gray) B.C.Stone & & $\mathrm{K}, \mathrm{O}, \mathrm{M}, \mathrm{H}$ \\
\hline
\end{tabular}

endangered and a continued decline in native arthropods, there is grave concern for the endangered Hawaiian flora and for their unique insular relationships with biodiversity as a whole. Even today, little is known about the life cycles, breeding system variations, and habitat preferences found in the Hawaiian flora (Sakai et al. 2002, Wood 2015), but it is known that Melicope rely on insects for pollination and birds for dispersal (Hartley 2001). Within Hawaiian Melicope five species are currently presumed extinct, 19 are federally listed as endangered, and with the inclusion of M. oppenheimeri, ten species fall into the Plant Extinction Prevention Program (PEPP) category, meaning there are 50 or fewer individuals remaining (see Table 1). Members of Hawaiian Rutaceae are currently in the process of being evaluated according to IUCN categories and criteria.

IUCN Red List Category. When evaluated using the World Conservation Union (IUCN) criteria for endangerment (IUCN 2001), Melicope oppenheimeri falls into the Critically Endangered (CR) category, which designates this species as facing a very high risk of extinction in the wild. Our formal evaluation can be summarized by the following IUCN hierarchical alphanumeric numbering system of criteria and subcriteria: CR B1 ab(i,ii,iii,v)+2ab(i,ii,iii,v); C2a(ii); D; which reflects a severely limited Extent of Occurrence (EOO) and Area of Occupancy (AOO) of less than $1 \mathrm{~km}^{2}$ and a wild population of only three individuals. It should be noted that seed collections of $M$. oppenheimeri have been made by Maui PEPP staff during routine monitoring and there is currently a single cultivated individual being grown at the Olinda Rare Plant Facility on East Maui.

\section{Acknowledgements}

We thank Keahi Bustamente, Greg Hansen, Jill Miller, Hank Oppenheimer, and Steve Perlman for their assistance in forest research. We acknowledge the National Tropi- 
cal Botanical Garden, the U.S. Fish and Wildlife Service, The Hawai'i State Department of Land and Natural Resources, and the Plant Extinction Prevention Program of Hawai'i for their continued focus on conservation. We appreciate the efforts of the Hawai'i State Division of Forestry and Wildlife and their Olinda Rare Plant Facility on East Maui, especially for the cultivation of Melicope oppenheimeri. Much gratitude to Alice Tangerini for the superb illustration, Timothy Flynn for assistance at the PTBG herbarium, and to Pedro Acevedo-Rodríguez and David Lorence for greatly improving this manuscript.

\section{References}

Appelhans MS, Keßler PJA, Smets E, Razafimandimbison SG, Janssens SB (2012) Age and historical biogeography of the pantropically distributed Spathelioideae (Rutaceae, Sapindales). Journal of Biogeography 39: 1235-1250. doi: 10.1111/j.1365-2699.2012.02686.x Appelhans MS, Wagner WL, Wood KR (2014a) Melicope balgooyi Appelhans, W.L. Wagner \& K.R. Wood, a new species and new record in Melicope section Melicope (Rutaceae) for the Austral Islands. PhytoKeys 39: 77-86. doi: 10.3897/phytokeys.39.7691

Appelhans MS, Wen J, Wagner WL (2014b) A molecular phylogeny of Acronychia, Euodia, Melicope and relatives (Rutaceae) reveals polyphyletic genera and key innovations for species richness. Molecular Phylogenetics and Evolution 79: 54-68. doi: 10.1016/j. ympev.2014.06.014

Appelhans MS, Wen J, Wood KR, Allan GJ, Zimmer EA, Wagner WL (2014c) Molecular phylogenetic analysis of Hawaiian Rutaceae (Melicope, Platydesma and Zanthoxylum) and their different colonization patterns. Botanical Journal of the Linnean Society 174: 425-448. doi: 10.1111/boj.12123

Burney DA, James HF, Burney LP, Olson SL, Kikuchi W, Wagner WL, Burney M, McCluskey D, Kikuchi D, Grady FV, Gage R II, Nishek R (2001) Fossil evidence for a diverse biota from Kauai and its transformation since human arrival. Ecological Monographs 71: 615-641.

Gregor HJ (1989) Aspects of the fossil record and phylogeny of the family Rutaceae (Zanthoxyleae, Toddalioideae). Plant Systematics and Evolution 162: 251-265. doi: 10.1007/ BF00936920

Harbaugh DT, Wagner WL, Allan GJ, Zimmer EA (2009) The Hawaiian Archipelago is a stepping stone for dispersal in the Pacific: an example from the plant genus Melicope $(\mathrm{Ru}-$ taceae). Journal of Biogeography 36: 230-241. doi: 10.1111/j.1365-2699.2008.02008.x

Hartley TG (2001) On the Taxonomy and Biogeography of Euodia and Melicope (Rutaceae). In: Allertonia Volume 8(1), National Tropical Botanical Garden, Lawa i, Kaua i, Hawai'i.

Hartley TG, Stone BC (1989) Reduction of Pelea with new combinations in Melicope (Rutaceae). Taxon 38: 119-123. doi: 10.2307/1220910

Hillebrand W (1888) Flora of the Hawaiian Islands: a description of their phanerogams and vascular cryptogams. Carl Winter, Heidelberg, Germany; Williams \& Norgate, London; B. Westermann \& Co., New York, 673 pp. 
James HF, Olson SL (1991) Descriptions of 32 new species of Hawaiian birds. Part II. Passeriformes. Ornithological Monographs 46: 1-88. doi: 10.2307/40166713

Kearns CA, Inouye DW, Waser N (1998) Endangered mutualisms: the conservation of plantpollinator interactions. Annual Review of Ecology and Systematics 29: 83-112. doi: 10.1146/annurev.ecolsys.29.1.83

Kingsford RT, Watson JEM, Lundquist CJ, Venter O, Hughes L, Johnson EL, Atherton J, Gawel M, Keith DA, Mackey BG, Morley C, Possingham HP, Raynor B, Recher HF, Wilson KA (2009) Major Conservation Policy Issues for Biodiversity in Oceania. Conservation Biology 23: 834-840. doi: 10.1111/j.1523-1739.2009.01287.x

Knobloch E, Mai DH (1986) Monographie der Früchte und Samen in der Kreide von Mitteleuropa. Rozpravy Ustredniho ustavu Geologickeho 47: 1-219.

Kreft H, Jetz W, Mutke J, Kier G, Barthlott W (2008) Global diversity of island floras from a macroecological perspective. Ecological Letters 11: 116-127.

Milberg P, Tyrberg T (1993) Naïve birds and noble savages - a review of man-caused prehistoric extinctions of island birds. Ecography 16: 229-250. doi: 10.1111/j.1600-0587.1993.tb00213.x

Muellner AN, Vassiliades DD, Renner S (2007) Placing Biebersteiniaceae, a herbaceous clade of Sapindales, in a temporal and geographic context. Plant Systematics and Evolution 266: 233-252. doi: 10.1007/s00606-007-0546-x

Olson SL, James HF (1991) Descriptions of 32 new species of Hawaiian birds. Part I. NonPasseriformes. Ornithological Monographs 45: 1-88. doi: 10.2307/40166794

Sakai AK, Wagner WL, Mehrhoff LA (2002) Patterns of endangerment in the Hawaiian flora. Systematic Biology 51: 276-302. doi: 10.1080/10635150252899770

Stone BC (1969) The Genus Pelea A. Gray (Rutaceae: Evodineae) A Taxonomic Monograph (Studies in the Hawaiian Rutaceae, 10) Phanerogamarum Monographiae Tomus III Verlag Von J. Cramer.

Wagner WL, Herbst DR, Sohmer SH (1999) Manual of the flowering plants of Hawai'i, revised edition with supplement by Wagner WL \& Herbst DR, pp. 1855-1918. University of Hawai'i Press, 1919 pp. in 2 volumes. (Bishop Museum Special Publication 97).

Wood KR (1997) Checklist of vascular plants of Kaho'olewa Ridge, West Maui, Pu'u Kukui to Kapohue (1585-1770 m elev.), National Tropical Botanical Garden Biological Report \#26, 11 pp.

Wood KR (1998) Ecosystem Observations \& Checklist of Vascular Plants, Waihe'e Valley (600-900 m elev.): including a summary evaluation of plant communities and rare species. National Tropical Botanical Garden Biological Report \#41, prepared for Maui County Board of Water Supply, Resource Planning Division, 50 pp.

Wood KR (2007) New plant records, rediscoveries, range extensions, and possible extinctions within the Hawaiian Islands. Bishop Museum Occasional Papers 96: 13-17.

Wood KR (2012) Possible Extinctions, Rediscoveries and New Plant Records within the Hawaiian Islands. Bishop Museum Occasional Papers 113: 91-102.

Wood KR (2014) Lose One, Lose Another, in The Bulletin, National Tropical Botanical Garden, Kalaheo, Hawai'i, USA 31: 8-13.

Wood KR (2015) Delissea rhytidosperma H. Mann (Campanulaceae) and Phyllostegia kahiliensis H. St. John (Lamiaceae) possibly extinct on Kauai, Hawaiian Islands. Bishop Museum Occasional Papers 116: 31-33. 